\title{
ACHIEVING THERMAL COMFORT AND SUSTAINABLE URBAN DEVELOPMENT IN ACCORDANCE WITH THE PRINCIPLES OF BIOCLIMATIC ARCHITECTURE: A CASE STUDY OF ULCINJ (MONTENEGRO)
}

\author{
BUJAR BAJÇINOVCI \\ Fakulteti i Ndërtimtarisë dhe Arkitekturës, Universiteti i Prishtinës, Pristina, Kosovo
}

Manuscript received: April 15, 2017

Revised version: July 4, 2017

\begin{abstract}
BAJÇINOVCI B., 2017. Achieving thermal comfort and sustainable urban development in accordance with the principles of bioclimatic architecture: A case study of Ulcinj (Montenegro). Quaestiones Geographicae 36(4), Bogucki Wydawnictwo Naukowe, Poznań, pp. 131-140, 10 figs, 4 tables, 10 figs.

AвstRAct: Human communities have always taken actions to create a healthier environment for living and working. Those efforts are best documented in the architectural structure everywhere, starting from ancient history to the present. It is assumed that the town of Ulcinj is one of the earliest cities on the Adriatic coast. The building morphology and urban structure of Ulcinj is 2,500 years old and is continued by multi-ethnical society. Hence, the urban structure of Ulcinj developed harmonically across the rock hills which encompass the city beach, forming the urban structure which is perceived as the unity of land and sea. The study investigates the Ulcinj urban structure, urban management, sustainable development, focusing on human comfort, and environmental actions with a view to accomplish better and more natural life. Bioclimatic passive design principles are associated with an environmental sustainable design, interrelated to the microclimate of the region, connected to the thermal, spatial, visual, acoustic, and air quality. The research method consists of empirical observation through the city and riviera. According to the conceptual findings of this paper, with a proper implementation of bioclimatic passive principles, the work seeks to indicate that it is possible to achieve a higher level than the current one. Hence, the huge number of tourists and overnight stays can make a difference in eco-tourism, and sustainable development if we can achieve energy efficiency, and preserve the natural resources in accordance with passive bioclimatic principles.
\end{abstract}

KEY WORDS: sustainable development, human geography, bioclimatic architecture, tourism

Corresponding author: Bujar Bajçinovci, Fakulteti i Ndërtimtarisë dhe Arkitekturës, Universiteti i Prishtinës, Pristina, Kosovo; e-mail:bujar.bajcinovci@uni-pr.edu

\section{Introduction}

It is assumed that the city of Ulcinj, in Montenegro, is one of the earliest cities on the Adriatic coast. Due to its morphological and geographical position, it was invaded numerous times. It is believed that Ulcinj was settled in the 1st millennium around the 5th century BC, by Illyrians, while in the 2nd (163) century
BC it was conquered by the Romans. After the empire was divided, the town remained as part of the Byzantine Empire. Ulcinj is located in the centre of the Ulcinj Riviera, in the southern part of Montenegro. This Riviera extends from Cape Mendra to the Buna River. The Buna forms a small delta with two divisions, the left one forming the border with Albania, and the right one being the part of Montenegro. Naturally 
surrounded by mountains, the location offered protection from persistent invaders. According to Claudii Ptolemaei's work 'Geographia', Ulcinj was mentioned as 'Ulkinion' (Ptolemaei, Augustus Nobbe 1843), onomastic studies of Ulcinj's name find the relations to the basis of the word 'Ulkuos' which in the Albanian language means 'wolf', also closely connected with the animal totem of the city of Ulcinj (OOUSI 2003: 227; Rymut 1981: 562). High urban structures of the city, the Citadel of Ulcinj, include the highest part of the rock hill in which the city was developed and spread out. The city fortress was an important trade centre in the sea area. In the feudal period, Ulcinj was several times the capital of the region. Moreover, the transport and trade were constantly developing along the Buna river. The trade connected to the transport in the direction of Kosovo and Macedonia was of particular importance. The building morphology and urban structure of Ulcinj is 2,500 years old and is continued by multi-ethnical society. Moreover, the urban structure of Ulcinj developed harmonically across the rock hills which encompass the city beach, forming the urban structure which is perceived as the unity of land and sea. The urban structure of Ulcinj is visually and geographically identified with its castle on the highest rock hill, surrounded by the Adriatic Sea. The castle has a magnificent architectural structure, which presents its security. Moreover, buildings in the region of Ulcinj were constructed from rocks, especially the Illyrian great wall, which encompasses the fortress. This wall was discovered on the upper layer of land on the castle structure, cyclopean walls were built up from large stone solids. Hence, we are dealing with the same building technique, where structures are made from solids as local bioclimatic materials, a construction tradition used over the centuries in Santorini-Thira in Greece. This construction technique is expressed along the coastline of the Adriatic Sea. Ulcinj is characterised by the Mediterranean climate and subtropical vegetation, the temperature in Ulcinj is suitable for human comfort, especially from May to October.

Moreover, during October, the air temperature corresponds to that of water (Bajçinovci 2017). The whole region is constructed and built by rocks, restructured and changed at different periods and historical epochs. Taking into account the environmental advantages mentioned above, two questions arise:

1. How have Ulcinj dwellers adapted to the hot Adriatic climate over the centuries?

2. What is the bioclimatic architecture and what does it represent in the context of human geography?

The Ulcinj urbanists have always looked at urban and sustainable development from the ecological perspective, otherwise the negligence in this matter would result in destruction, famine and social disintegration. It can be clearly noted that the necessity to create the harmony between human thermal comfort and the ideas concerning the environment brings authentic simple solutions. The building morphology and urban structure of Ulcinj are perceived as the environmental unity of land and sea, with their natural passive methods of cooling. Moreover, as stated by Buček, in relation to urban management, "We can consider urban development policy as a very traditional part of socio-political life, with more typical fields of activity" (Buček 2016). Regarding the environmental premises, we can clearly cite the United Nations, The 2030 Agenda for Sustainable Development: The actions over the next fifteen years, in the areas of critical importance for humanity and the planet:

\footnotetext{
"We are determined to protect the planet from degradation, including through sustainable consumption and production, sustainably managing its natural resources and taking urgent action on climate change, so that it can support the needs of the present and future generations" (UN 2017).
}

Bioclimatic architecture is associated with the environmental sustainable design of buildings interrelated to the microclimate of the region, aiming at providing the thermal, spatial, visual, acoustic, and air quality human comfort. Furthermore, to satisfy the above-mentioned criteria it is necessary to use all possible renewable sources of energy (Bajçinovci 2017). So, we generally aim at building up the structures which are in harmony with the functionality of facilities and nature in order to achieve human comfort. How can those design principles influence healthier living, sustainable tourism and vice versa? In particular, sustainable tourism has great potential for development in the Ulcinj 
Riviera, but actually it is not much exploited and promoted. Furthermore, sustainable tourism can be supported by cultural tourism, and sustainable tourist development.

The objective of this paper is to address three dimensions of sustainability that relate to the urban structure development taking into account human comfort, the microclimate and environment:

- providing human comfort based on environmental awareness;

- achieving the best possible levels of energy efficiency, with passive cooling methods;

- preserving natural local resources, and the environment.

Moreover, "urban air temperature is gradually rising in all cities" (Yan et al. 2012). Is it possible to achieve a higher level of human thermal comfort, using bioclimatic passive principles, average annual climate conditions, and the advantages of natural flows of climate? This paper presents the following environmental actions:

- more natural use of the atmosphere characteristics;

- promotion and implementation of the vernacular building techniques;

- promotion of the environmental awareness, and sustainable human development.

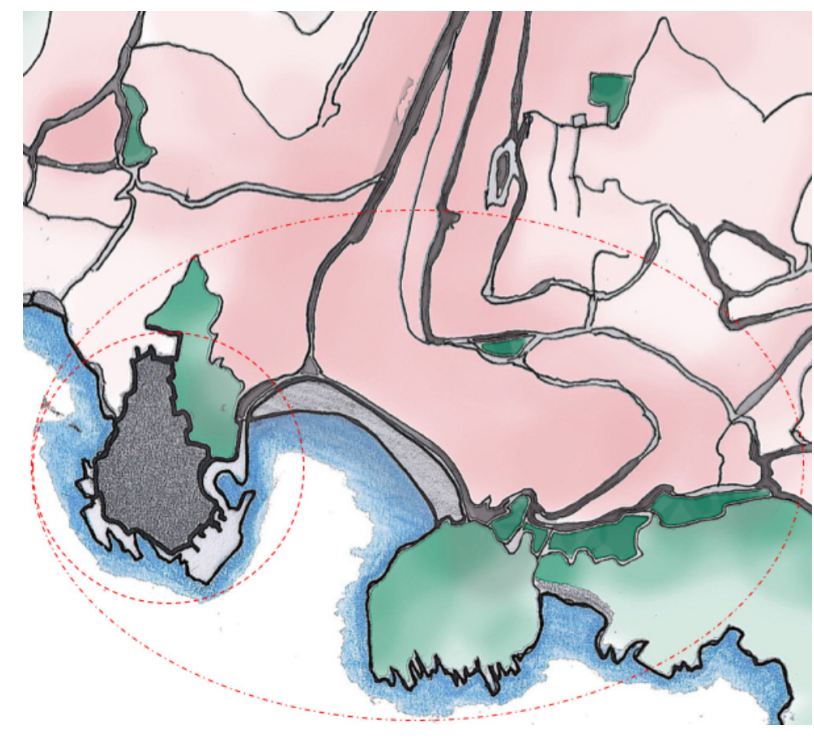

Fig. 1. Urban development of the Ulcinj Riviera, the city castle and urban morphology.

\section{Materials and methodology}

Communities have always taken environmental actions to create a healthier living and working environment. Those efforts are documented best in the architectural structure everywhere, from ancient history to the present time.

Hence, what exactly is the human geography? The term is defined by Johnston: "Human geography deals with the study of people and their communities, cultures, economies and interactions with the environment" (Johnston 2000), or the term defined by the British Library: "Human geography focuses on the spatial organisation of human activity and its relations with the physical environment" (British Library 2017).

On the other side of the symbiosis, what exactly is the meaning of human comfort? According to the ANSI/ASHRAE Standard 55-2010, thermal comfort is defined as: "that condition of mind which expresses satisfaction with the thermal environment and is assessed by subjective

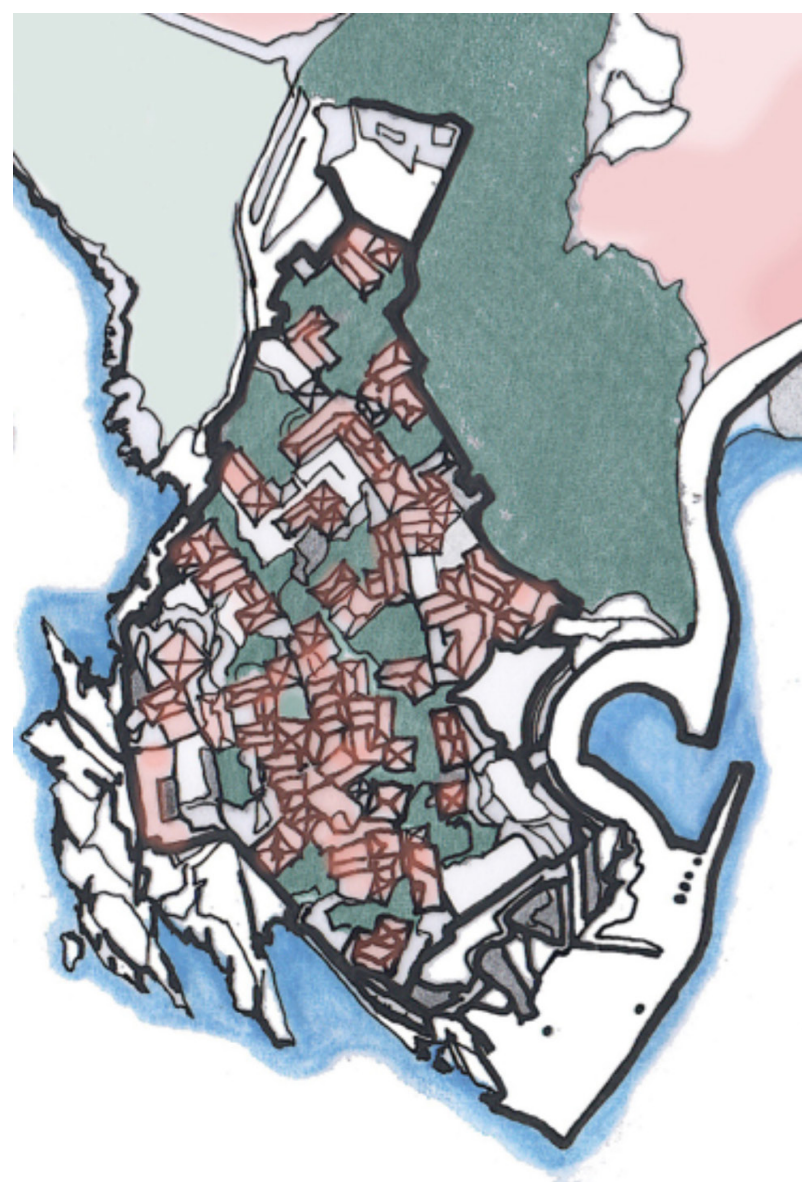

Fig. 2. Urban structure of the city of Ulcinj, focus on the City Citadel. 


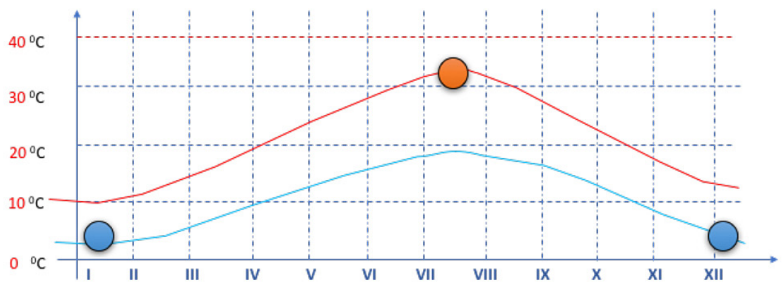

Fig. 3. Average monthly outdoor temperatures (max.min.) for Ulcinj, (IHMS Montenegro 2015).

evaluation". The study presented in this paper investigated the Ulcinj urban structure, urban management, and sustainable development in accordance with the principles of bioclimatic architecture. It focuses on human geography, human comfort, and environmental actions aimed at achieving better and healthier living conditions. The research seeks to review the literature to gain better understanding of sustainable and urban development. Materials and methods consist in the empirical observation through the urban and spatial zone. The efforts are made to receive data and information that are more accurate within the established symbiosis of the urban structures planning and human geography, especially focused on sustainable environmental actions regarding the quality of life. The research was conducted through the municipal urban documentation and personal hand drawings. The materials collected include maps, photography, and geographical attributes of the space. The supplement data for this research are founded on the analysis of the existing state of urban management, and the houses in the castle, in which the natural ventilation was preserved to this day.

The climate of the Ulcinj Riviera is identified as Mediterranean one with subtropical vegetation. The Ulcinj Riviera is the most representative district with maximum daylight hours on the Adriatic. There are 220 days of annual average insolation, namely 2,800 daylight hours in a year

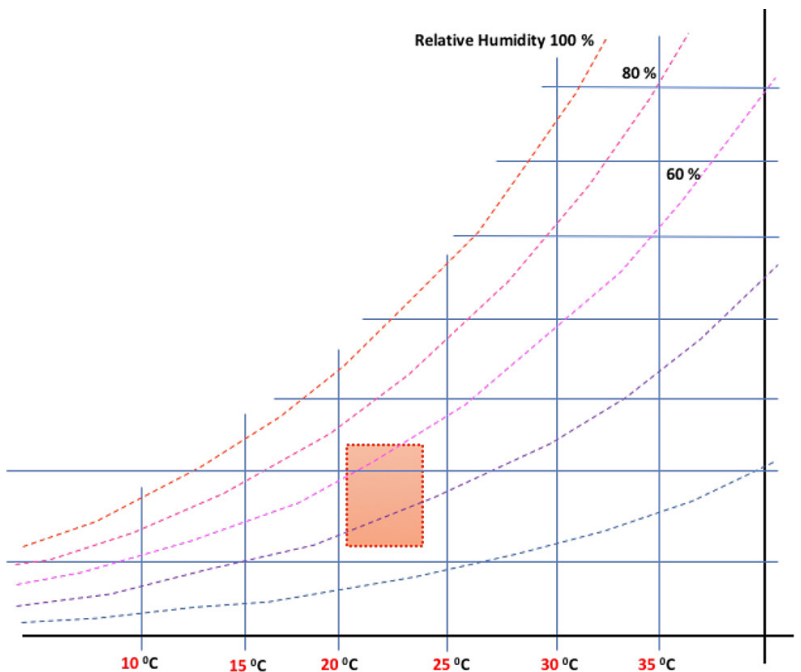

Fig. 5. Psychometric chart, comfort zone of human thermal comfort.

(IHMS Montenegro 2016). This research aims to acknowledge sustainable development with respect to bioclimatic architecture principles, urban heritage dimensions related to the sustainable architecture and urban planning in relation to human geography, with the following key features:

- improvement in the quality of human comfort in the housing;

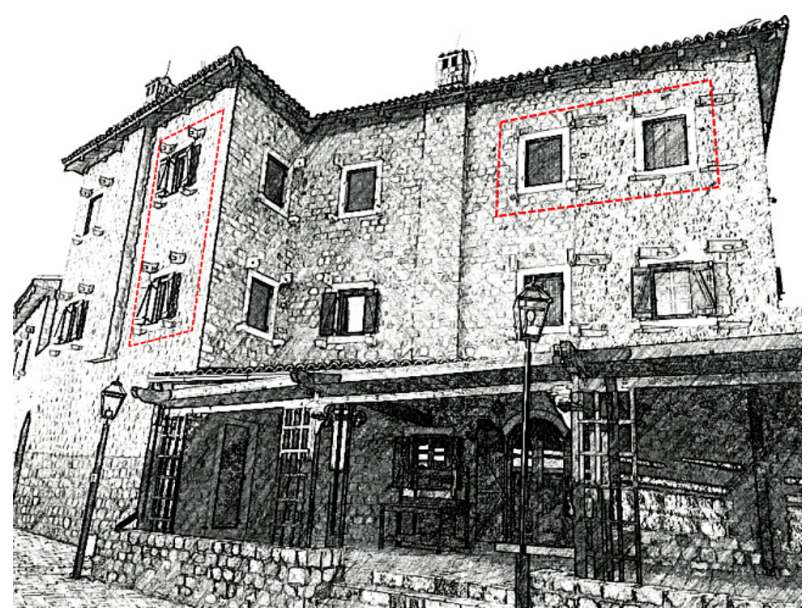

Fig. 6. Old house, old structure of the city castle.

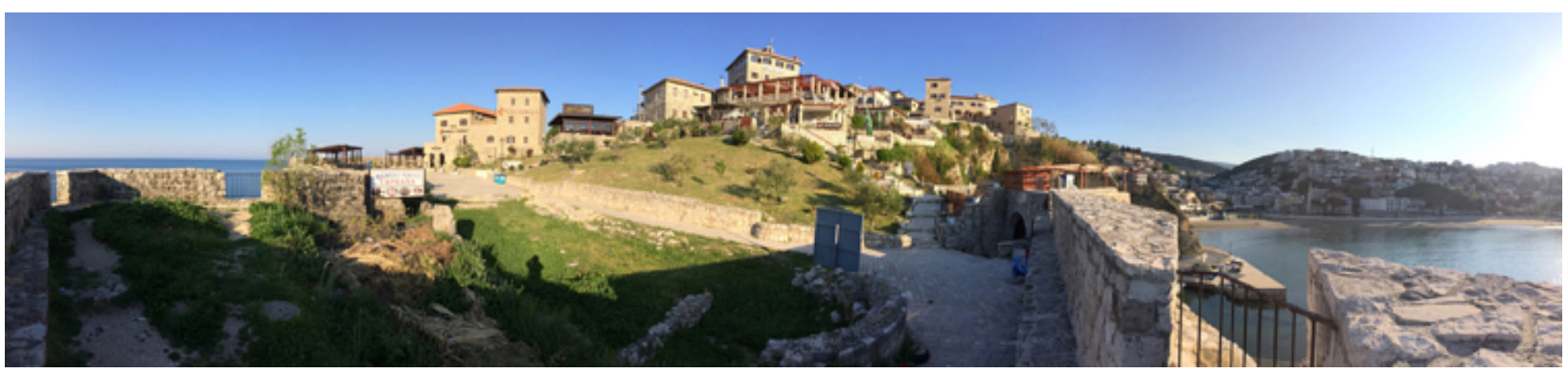

Fig. 4. Silhouette of the urban structure of Ulcinj, the city castle in the centre. 

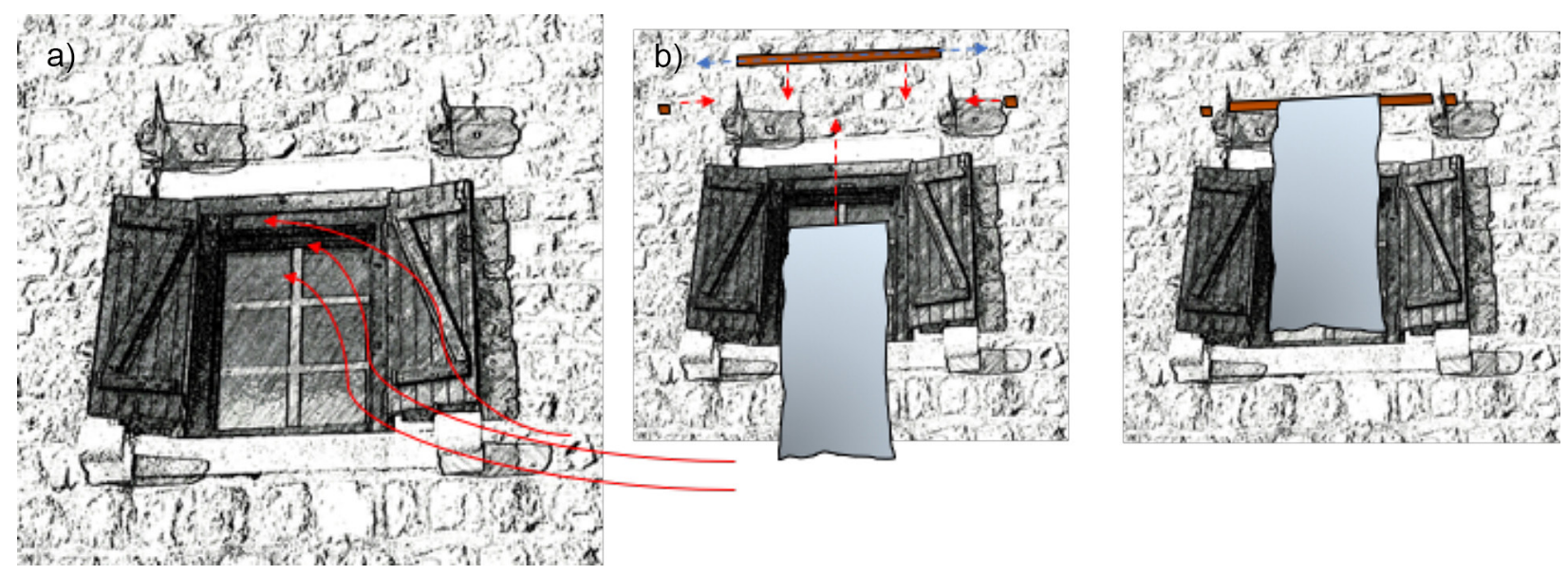

Fig. 7a. Existing natural ventilation.

Fig. 7b. Revitalised method for existing natural ventilation, ensuring the needed shade and humidity in the hot season. Architectural structure of the city of Ulcinj.

- natural ventilation with no harmful impact for the environment;

- advanced, natural methods to raise the quality of life.

The city of Ulcinj lacks electricity in the summer season, when power consumption is high as a result of a heavy tourist demand. Moreover, the municipality of Ulcinj lacks sufficient experience in the field of sustainable management and contemporary treatment of natural resources. We argue that the Ulcinj Riviera does not use sustainable resources now, and urban development can be further strengthened if proper environmental actions are taken. There is a huge bioclimatic and microclimate benefit potential which is not used. Why is that so? According to the Monstat, the Statistical Office of Montenegro, in the Ulcinj

Table 1. Tourist arrivals and overnight stays by municipalities, Montenegro, August 2016 (Montstat 2016).

\begin{tabular}{|l|c|c|c|c|c|c|c|c|}
\hline \multirow{2}{*}{ Municipality } & \multicolumn{5}{|c|}{ Tourist arrivals } & \multicolumn{3}{c|}{ Overnight stays } \\
\cline { 2 - 9 } & Foreign & Domestic & Total & Structure & Foreign & Domestic & Total & Structure \\
\cline { 2 - 9 } & -1 & -2 & $(3)=(1)+(2)$ & $(3) \mathrm{u} \%$ & -1 & -2 & $(3)=(1)+(2)$ & $(3) \mathrm{u} \%$ \\
\hline Total & 545,234 & 38,042 & 583,276 & 100.0 & $3,801,146$ & 237,192 & $4,038,338$ & 100.0 \\
\hline Andrijevica & 12 & 25 & 37 & 0.0 & 14 & 30 & 44 & 0.0 \\
\hline Bar & 62,737 & 1,463 & 64,200 & 11.0 & 513,492 & 8,941 & 522,433 & 13.0 \\
\hline Berane & 175 & 91 & 266 & 0.0 & 207 & 124 & 331 & 0.0 \\
\hline Bijelo Polje & 513 & 225 & 738 & 0.1 & 1,138 & 594 & 1,732 & 0.0 \\
\hline Budva & 238,485 & 26,709 & 265,194 & 45.5 & $1,669,283$ & 170,278 & $1,839,561$ & 45.6 \\
\hline Cetinje & 1,642 & 629 & 2,271 & 0.4 & 2,464 & 2,990 & 5,454 & 0.1 \\
\hline Danilovgrad & 276 & 22 & 298 & 0.1 & 375 & 44 & 419 & 0.0 \\
\hline Herceg Novi & 103,271 & 2,037 & 105,308 & 18.0 & 797,011 & 20,202 & 817,213 & 20.2 \\
\hline Kolasin & 2,846 & 813 & 3,659 & 0.6 & 6,867 & 1,925 & 8,792 & 0.2 \\
\hline Kotor & 26,235 & 198 & 26,433 & 4.5 & 157,347 & 1,033 & 158,380 & 3.9 \\
\hline Mojkovac & 324 & 21 & 345 & 0.1 & 531 & 41 & 572 & 0.0 \\
\hline Niksic & 1,043 & 130 & 1,173 & 0.2 & 3,688 & 477 & 4,165 & 0.1 \\
\hline Plav & 412 & 15 & 427 & 0.1 & 748 & 40 & 788 & 0.0 \\
\hline Pljevlja & 373 & 290 & 663 & 0.1 & 1,073 & 999 & 2,072 & 0.1 \\
\hline Pluzine & 2,162 & 112 & 2,274 & 0.4 & 3,120 & 150 & 3,270 & 0.1 \\
\hline Podgorica & 9,042 & 1,274 & 10,316 & 1.8 & 16,736 & 6,088 & 22,824 & 0.6 \\
\hline Rozaje & 221 & 83 & 304 & 0.1 & 248 & 100 & 348 & 0.0 \\
\hline Savnik & 96 & 36 & 132 & 0.0 & 137 & 36 & 173 & 0.0 \\
\hline Tivat & 19,366 & 552 & 19,918 & 3.4 & 203,810 & 3,432 & 207,242 & 5.1 \\
\hline Ulcinjj & 65,384 & 2,486 & 67,870 & 11.6 & 403,573 & 16,419 & 419,992 & 10.4 \\
\hline Zabljak & 10,619 & 831 & 11,450 & 2.0 & 19,284 & 3,249 & 22,533 & 0.6 \\
\hline & & & & & & & & \\
\hline
\end{tabular}


Table 2. Overnight stays in collective accommodation in Montenegro (Montstat 2016).

\begin{tabular}{|c|c|c|c|c|c|}
\hline \multirow{2}{*}{ Year } & Total & Domestic tourists & Foreign tourists & \multirow{2}{*}{$\begin{array}{c}\text { Index level } \\
2010=100\end{array}$} & \multirow{2}{*}{$\begin{array}{c}\text { Annual change, } \% \\
(y / y-1)\end{array}$} \\
\hline & $(1)=(2)+(3)$ & $(2)$ & (3) & & \\
\hline 2010 & $3,014,418$ & 442,689 & $2,571,729$ & 100.0 & \\
\hline 2011 & $3,170,519$ & 427,105 & $2,743,414$ & 105.2 & $5.2 \%$ \\
\hline 2012 & $3,172,900$ & 394,129 & $2,778,771$ & 105.3 & $0.1 \%$ \\
\hline 2013 & $3,397,308$ & 385,495 & $3,011,813$ & 112.7 & $7.1 \%$ \\
\hline 2014 & $3,085,634$ & 364,816 & $2,720,818$ & 102.4 & $-9.2 \%$ \\
\hline 2015 & $3,247,820$ & 403,926 & $2,843,894$ & 107.7 & $5.3 \%$ \\
\hline 2016 & $3,521,897$ & 407,810 & $3,114,087$ & 116.8 & $8.4 \%$ \\
\hline
\end{tabular}

Riviera every tourist year shows an increase, as presented in Table 1.

Moreover, Ulcinj ranked fourth in Montenegro in terms of the number of arrivals and overnight stays in August 2016. Additionally, Ulcinj with over a half million of arrivals and overnight stays in just one month of the summer season, represents a desirable research model as one of the many Adriatic municipalities in which environmental actions can be implemented as an example.

As presented in Table 2, in each tourist year there are approximately 3,500,000 overnight stays in Montenegro, half of this total being domestic accommodation.

\section{Discussion}

The urbanists of Ulcinj with ecology in mind have adopted and adapted the natural, ecological design principles over the centuries. Moreover, those actions can be clearly seen in building techniques that have been applied until the present. The use of and benefit from a mass of vegetation, creating natural shade and enriching the air with oxygen in magnificent quantities from the diversity of plants, is the first and crucial step in implementing the natural and plain design principles for freshening and oxygenation. Sustainable development is a global issue, as presented graphically above, and the old Ulcinj inhabitants have found the method of achieving climate comfort during the hot season. Those principles of bioclimatic architecture are based on the laws of physics, thus achieving natural ventilation for their homes through adopting passive methods of cooling, further promoting sustainable spatial environmental development; they represent the most preferred urban development strategies. Moreover, this research is inspired by architectural details presented in each window of the houses located in the Ulcinj Citadel, with specially prepared stones with holes in them to hold the timber sticks used as a support for a moistened wrap. According to the research findings, it was a simple and effective method to provide hot housing units with so much needed shade and humidity. Hence, the use of local architectural materials for building structures presents a further step of the sustainable environmental design. Using rocks, stones and timber as primary material to build housing structures reveals a holistic approach to interrelation between communities and the specific climate of the Adriatic.

The city of Santorini (Thira) in Greece corresponds with Ulcinj in this matter, implementing passive bioclimatic principles at the same level. Santorini is an island in the southern Aegean Sea, and is well known for its limestone whitewashed houses with small windows and doors, and thick plaster walls, architectural features that keep rooms cooler. The same principles of achieving human thermal comfort are used, naturally except for those that are specific in terms of the microclimate and geography. Furthermore, there is the same urban structure of a high density of small buildings and their massive construction intended to protect them against the sun and strong sea winds. Hence, there are specific vaults and cross vaults in the built structures which characterise the specific architectural design of Thira. Those thin vaulted roofs in Thira are originally

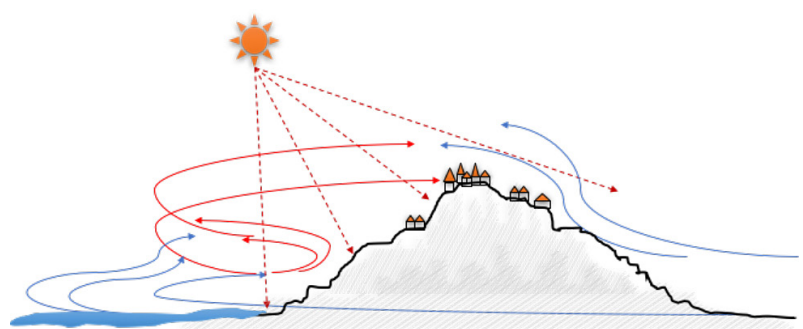

Fig. 8. Interrelation of climate and human geography as microclimate symbiosis. 


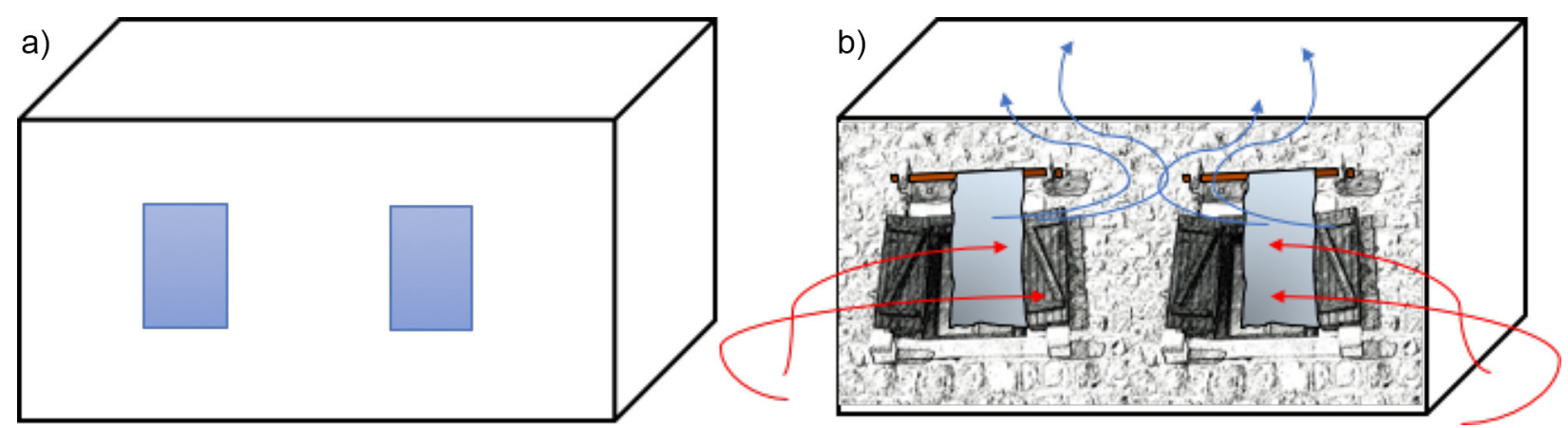

Fig. 9. a) A typical housing unit, as a model for research. b) Preferred measures.

implemented in relation to the pitched roofs of the Ulcinj architecture. Hence, vaulted roofs in Thira with a small opening in the front façade or the upper part of a vault can better maintain the indoor temperature at the comfort level, as opposed to the classic pitched roofs. Those fundamental passive bioclimatic actions use the universal principles of energy flow and regional microclimatic features of the region, which originally results from necessity rather than human choices.

A holistic environmental approach to the architectural design in accordance with bioclimatic principles is universally present and wide disposable, thus it can be used as a working model in finding the best environmentally possible solutions, with actions for the implementation of a better quality of everyday life. If we look deeper into the architectural design according to the bioclimatic principles, we need to adopt, adapt and implement the energy efficiency, natural ventilation, avoiding light and acoustic pollution, and most importantly, preserving the quality of the air (Bajçinovci 2017).

To achieve hygienic and thermal comfort, a minimum amount of outside air should flow into a housing unit per person/hour. The following calculation is made for minimum fresh air exchange rates, based on research carried out in Ulcinj. Moreover, it is a designer's obligation to ensure that the indoor temperature is quite acceptable (Szokolay 1997).

Table 3. Amounts of $\mathrm{CO}_{2}$, water vapor and heat that person releases within an hour (Krasniqi et al. 2004).

\begin{tabular}{|l|c|c|c|c|c|}
\hline \multicolumn{2}{|c|}{} & $\begin{array}{c}\mathrm{CO}_{2} \\
{[1 / \mathrm{h}]}\end{array}$ & $\begin{array}{c}\text { Substances } \\
\text { with odor }\end{array}$ & $\begin{array}{c}\text { Water vapor } \\
{[\mathrm{gr} / \mathrm{h}]}\end{array}$ & $\begin{array}{c}\text { Heat } \\
{[\mathrm{W}]}\end{array}$ \\
\hline \multirow{2}{*}{ Person } & At rest & 20 & Measured & 70 & 120 \\
\cline { 2 - 6 } & $\begin{array}{c}\text { In } \\
\text { work }\end{array}$ & 70 & $\begin{array}{c}\text { Not } \\
\text { measured }\end{array}$ & 130 & 300 \\
\hline
\end{tabular}

Dimensions for a typical housing unit in this study:

$$
\mathrm{V}=6 \times 5 \times 2.8=84 \mathrm{~m}^{3}
$$

where:

$\mathrm{V}=$ volume of a housing unit $\left[\mathrm{m}^{3}\right]$

presuming the needed, minimum fresh air rate in this research model is $20 \mathrm{~m}^{3} / \mathrm{h}$. For a calculation, when the outside temperature rises above $+28^{\circ} \mathrm{C}$, a fresh air rate can be reduced to $30 \%$, in order to maintain and preserve the energy. The minimum fresh air rate change, the exchange of the air in a housing unit per hour, results from a wide range of factors, such as:

- air rate change, volume/h are required for cooling and thermal comfort;

- essential intake of air volume in order to achieve human comfort;

- intake of the fresh air, achieving the desired humidity in arid and hot climate spaces.

- quality air rate change, preserving hygienic comfort.

Air change rate is expressed as:

$$
\begin{gathered}
\mathrm{n}=3600 \mathrm{Q} / \mathrm{V} \\
\mathrm{n}=36000.2 / 84=8.5
\end{gathered}
$$

where:

$\mathrm{n}=$ air changes per hour $[\mathrm{ac} / \mathrm{h}]$,

Table 4. Values of overpressure and under pressure in relation to wind velocity (Krasniqi et al. 2004).

\begin{tabular}{|c|c|c|}
\hline $\begin{array}{c}\text { Wind velocity } \\
{[\mathrm{m} / \mathrm{s}]}\end{array}$ & $\begin{array}{c}\text { Overpressure } \\
{[\mathrm{Pa}]}\end{array}$ & $\begin{array}{c}\text { Under pressure } \\
{[\mathrm{Pa}]}\end{array}$ \\
\hline 2 & 2.9 & 0.9 \\
\hline 5 & 15.6 & 4.9 \\
\hline 10 & 64.7 & 21.5 \\
\hline
\end{tabular}


$Q=$ fresh air flow through a housing unit $\left[\mathrm{m}^{3} / \mathrm{s}\right]$,

$\mathrm{V}=$ volume of a housing unit $\left[\mathrm{m}^{3}\right]$.

Therefore, in relation to individual diversities it is quite common to conclude that the presented thermal comfort zone is not generally confirmed. Therefore, each individual subjectively perceives thermal comfort. Thus, evidently there are admissible differences (Krasniqi, Selimaj 2014).

Hence, we always aim to 'reach' the $90^{\text {th }}$ percentile of human thermal satisfaction, therefore, the chart of a comfort zone includes those differences. Regarding the individual differences there are other crucial factors to be considered:

- human habits in relation to thermal satisfaction;

- age, and target group;

- gender;

- visual perception, and noise pollution;

- ability of human metabolism to adapt;

- life style.

Moreover, according to Fanger, there are five other factors to consider for the calculation: air velocity, humidity, radiant temperature, metabolic heat, and clothing resistance. All of these parameters must be in balance to be considered as satisfactory (Fanger 1982).

In view of all the contemporary challenges associated with the development of technology, lifestyle, a lack of time to be in contact with nature, and global world trends, a new way of living has developed. However, "Humanity grows more and more intelligent, yet there is clearly more trouble and less happiness daily. How can this be so? When a society misuses and ignores holistic wisdom, its people forget the benefits of a plain and natural life" (Walker 1995). The Citadel of Ulcinj is a site with a great municipal impact and the main attraction in the town. Expectations are high as to the role the fortress can play in the sustainable tourism of the Ulcinj Riviera. These expectations have not been met, however, and in order to change that, a lot of effort is required to make the fortress a sustainable tourist site. With such an attractive location, the local community and international tourists frequently visit the fortress. With the society moving towards greater energy demands and environmental sustainability responsibilities, a municipality and authorities must reconsider reusing historical buildings before new ones are to be planned, and concurrently promote the ecological awareness regarding the quality of life. Finally, what represents architectural bioclimatic design principles in relation to energy efficiency and sustainable tourism? What is the common understanding of the terms: urban management and sustainable urban design? A natural cross ventilation system is the best way to improve air rate freshness. It uses the principles of microclimate physics, considering the wind velocity and air pressure differences. In terms of urban and human geography, those attributes of nature as the 'chief architect' can be used in general situations and conditions when we need and demand environmental design results, strengthened by eco-tourism marketing through raising the awareness of the local heritage and sustainable development (UNESCO 2015). Hence, in this research, housing units and all the houses in the Ulcinj Citadel can greatly utilise those bioclimatic design principles, as a sustainable design strategy. Moreover, those passive cooling methods are in line with legal guidelines for preserving the national built-up heritage, especially in situations like this research when we are dealing with castle two millennia old, thus aiming at sustainable development, and environmental actions as healing strategies (Bajçinovci, Jerliu 2016).

\section{Conclusion}

Contemporary challenges, associated with the development of technology, life style, lack of time to be in contact with nature, and global world trends, have created a new way of living. Sustainable development is a global concern; therefore, it cannot be addressed only locally. Moreover, national and global actions are irreplaceable and crucially necessary. The current state of environmental and urban planning requires specific responsibilities and activities, especially when this state is directly linked to the quality of life and public health. Hence, according to the conceptual findings of this study, we prefer natural ventilation in an urban pattern where those natural techniques are preferable and can be used. Furthermore, taking a sustainable strategy into account, it may be necessary to reconsider the use of passive cooling 


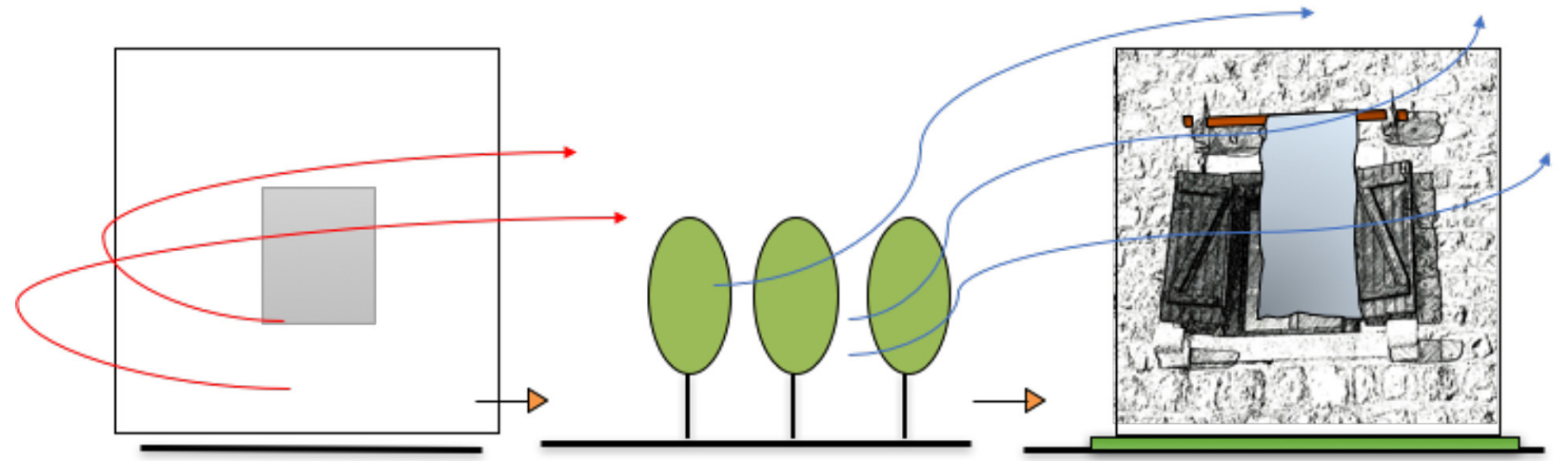

Fig. 10. Differences in the use of urban sustainable design, preferred revitalisation method for natural cross ventilation.

and ventilation, which provide housing units with shade and humidity. Hence, the research model of one housing unit, analysed in terms of natural ventilation in approximately $84 \mathrm{~m}^{2}$, at present inhabited by a single family of four, and accompanied by tourists in the summer season. According to the conceptual findings, with a proper implementation of passive bioclimatic principles, human thermal comfort can be more effective than at present under average annual climate conditions. Moreover, in view of the current climate conditions, heating in the period from October to November and from March to April is expected to be suspended. Sustainable development strategies with natural ventilation methods, can gain savings in energy for cooling, from May to June and from September to October, strengthened by the freshness of vegetation nearby and a cooling breeze. Thus, some considerable savings for air-condition or mechanical ventilation can be expected. Based on the presented conceptual findings, reinforced by the best practices quoted in literature and in the 2030 Agenda for Sustainable Development (European Commission UN 2017), we recommend the implementation of the passive bioclimatic principles, and more specifically:

- adopting passive methods for cooling;

- promoting sustainable design to increase the qualitative land use;

- promoting and maintaining ecological awareness and a quality of life;

- designing and developing programs aiming to promote and implement sustainable tourism;

- promoting sustainable development, and human geography as healing strategies;
- making wide marketing for eco-tourism, through raising awareness of the local heritage;

- raising awareness of positive impact on the environment, and communities.

According to the World Energy Council and complying with sustainable development principles, governments should recognise and include the size, scale, pace and needed development in energy, thus adopting and adapting the environmental actions which can further strengthen sustainable human development. Furthermore, municipalities must also establish sustainable development strategies and appropriate policies to the required assignment (WEC 2009) taking vital and responsible actions of management strategies for natural resources (SME 2004). The World Energy Council also recommends holistic coordination between the involved parties, which must be at the highest level. Moreover, recommendations go further to appoint one ministry devoted to a particular sustainable strategy and responsible for the management of energy and climate initiatives, and further, for consultations with other ministries if necessary. Nevertheless, we argue that there are 620,000 Montenegrin citizens as per 2011 registration (Montstat 2011), and as evidenced in this paper, from 2011 to the present, each fiscal year in Montenegro, there are approximately 3,500,000 overnight stays in collective accommodation, half of this total being domestic accommodation. Related to this data, a huge number of tourists and overnight stays can make a difference in eco-tourism, and sustainable development if we can achieve energy efficiency, and preserve the natural resources according to passive bioclimatic principles. 


\section{References}

ASHRAE 2010. ANSI/ASHRAE Standard 55-2010. Atlanta: American Society of Heating, Refrigerating and Air-Conditioning Engineers, Inc. https://sustainabilityworkshop.autodesk.com/buildings/human-thermal-comfort\#1AS HRAE (accessed 3 January 2017).

Bajçinovci B., Jerliu F., 2016. Achieving energy efficiency in accordance with bioclimatic architecture principles. Environmental and climate technologies. doi: 10.1515/ rtuect-2016-0013, vol. 18, pp. 54-63, Online: https:// www.degruyter.com/view/j/rtuect.2016.18.issue-1/ rtuect-2016-0013/rtuect-2016-0013.xml (accessed 3 April 2017).

Bajçinovci B., 2017. Ecological architecture in response over the centuries. A case study: Ulcinj of Adriatic Sea. Ecology, Environment and Conservation 23(2).

British Library 2017. Human geography. Help for researchers. http://www.bl.uk/reshelp/findhelpsubject/socsci/humangeog/humangeography.html (accessed 5 April 2017).

Buček J., 2016. Urban development policy challenges in east-central Europe: Governance, city regions and financialisation. Quaestiones Geographicae 35(2). Bogucki Wydawnictwo Naukowe, Poznań.

European Commission, UN, 2017. The 2030 Agenda for Sustainable Development. https:/ / sustainabledevelopment. un.org/post2015/transformingourworld (accessed 20 March 2017).

Fanger P.O., 1982. Thermal comfort. Robert E. Krieger Publishing Comp., Malabar, FL.

IHMS 2016. Institute of Hydrometeorology and Seismology, Montenegro, Climatology. http://195.66.163.23/misc. php?text $=27 \&$ sektor $=1$ (accessed 10 September 2012).

Krasniqi F., Selimaj R., Malsiu I., 2004. Instalimet Makinerike. Universiteti i Prishtinës, UP.

Krasniqi F., Selimaj R., 2014. Analysis of human thermal comfort in Kosovo conditions. Academy of Sciences and Arts of Kosovo. Faculty of Mechanical Engineering, UP.
MONSTAT (Statistical Office of Montenegro) 2017. Provider of official statistics in Montenegro's statistical system. http://www.monstat.org/eng/index.php (accessed 25 March 2017).

OOuSI 2003. Österreichische Osthefte 45(1-2): 227. Österreichisches Ost-Südosteur.Institut.

Ptolemaei C., 1843. Geographia. Edidit Carolus Fridericus Augustus Nobbe. University of Michigan. https://catalog. hathitrust.org/Record/002504277 (accessed 5 May 2017).

Rymut K., 1981. Gegenstand und Methoden der Onomastik. Acta tricesimi conventus virorum doctorum omnium gentium onomasticae excolendae. Onomastics.

SME (Swedish Ministry of the Environment) 2004. A Swedish Strategy for Sustainable Development Economic, Social and Environmental, Stockholm. http:/ / www.government.se/49b73c/contentassets/3f67e0b1e47b4e83b542ed6892563d95/a-swedish-strategy-for-sustainable-development-summary (accessed 9 June 2017).

Szokolay S., 1997. Thermal comfort in the warm-humid tropics. http://anzasca.net/wp-content/uploads/2014/08/02_ANZASCA_1997_Sokolay.pdf (accessed 22 June 2017).

UNESCO 2016. United Nations Educational, Scientific and Cultural Organization (UNESCO). http://en.unesco. org/system/files/244834e1.pdf (accessed 21 June 2017).

Walker B., 1995. Hua Hu Ching: The unknown teachings of Lao Tzu. Harper Collins.

WEC (World Energy and Climate Policy) 2009. 2009 Assessment. World Energy Council. London, United Kingdom, 2009. London, UK. www.worldenergy.org (accessed 15 January 2017).

Yan H., Wang X., Hao P., Dong L., 2012. Study on the microclimatic characteristics and human comfort of park plant communities in summer. The 18th Biennial Conference of International Society for Ecological Modelling. Procedia Environmental Sciences 13: 755-765. 